\title{
INSIGHT OF BASIC EDUCATION TEACHERS IN THE STATE OF RIO GRANDE DO SUL, BRAZIL, ON ENVIRONMENTAL EDUCATION
}

\author{
Julia Gastmann ${ }^{1}$ \\ Ana Paula Jaeger ${ }^{2}$ \\ Elisete Maria de Freitas ${ }^{3}$
}

\begin{abstract}
This study aimed to understand the perception of teachers from the final years of Elementary Schools from Rio Grande do Sul, Brazil, about Environmental Education and how they practice it. A questionnaire was elaborated and sent to teachers from different schools and cities of Rio Grande do Sul state through Google Forms. It was observed that the teachers recognize the importance of Environmental Education, and in general agree that it has to be worked in an interdisciplinary manner, however, they don't have the education to do so; they don't know the existent Brazilian legislation about the theme and don't effectively comprehend the meaning of teaching Environmental Education. The practices in the schools lack further development and meaning, being incapable of attending to its objective of shaping ecologic and critical individuals that are aware of their role in the preservation of the environment.
\end{abstract}

Keywords: Environmental Awareness; Environmental Education Practices; Environmental Educators.

Resumo: O objetivo do estudo foi entender a percepção que professores dos anos finais do Ensino Fundamental do Rio Grande do Sul, Brasil, possuem sobre Educação Ambiental e como a realizam. Um questionário foi elaborado e enviado aos professores de diferentes escolas e municípios do Estado usando o Google Formulários. Verificou-se que os professores reconhecem a importância da Educação Ambiental e concordam que ela deve ser trabalhada de forma interdisciplinar. No entanto, não possuem formação para a sua prática; desconhecem a legislação existente no Brasil sobre o tema e não compreendem efetivamente o que significa realizar Educação Ambiental. As práticas nas escolas carecem de aprofundamento e significação, não sendo capazes de atender ao seu objetivo, que é o da formação de sujeitos ecológicos, críticos e conscientes do seu papel na preservação ambiental.

Palavras-chave: Conscientização Ambiental; Práticas de Educação Ambiental; Educadores Ambientais.

\footnotetext{
${ }^{1}$ Universidade do Vale do Taquari. E-mail: julia.gastmann@universo.univates.br. Link para o Lattes: http://lattes.cnpq.br/9905478395359239

2Universidade do Vale do Taquari. E-mail: ana.jaeger@universo.univates.br. Link para o Lattes: http://lattes.cnpq.br/5756476590589626

3Universidade do Vale do Taquari. E-mail: elicauf@univates.br.

Link para o Lattes: http://lattes.cnpq.br/7345668866571738
} 


\section{Introduction}

We are currently facing, on a global scale, climate changes and other environmental issues that directly threaten the survival of humanity itself as a result of the pressure exerted on the environment caused by the adopted way of life which overly uses the available natural resources (ROOS; BECKER, 2012). In Brazil, the National Environmental Education Program (BRASIL, 2005) had already highlighted as serious the threat to biodiversity due to air pollution, soil degradation, and contamination of water resources, although problems such as deforestation, fires, among others, can also be mentioned (GELAIN et al., 2012; SERRAGLIO et al., 2018). It is in this context and as an attempt to contribute to the reduction of the negative impacts generated by human activities on the environment that Environmental Education (EE) emerges (BURSZTYN; BURSZTYN, 2013; LAYRARGUES; LIMA, 2014).

For Profice (2016), EE is responsible for contributing to the dissemination of scientific knowledge, explaining environmental processes, the consequences of human actions on the environment, and motivating people to search for solutions to environmental problems. Furthermore, EE would have, as its ultimate objective, to educate individuals to be critical and capable of appropriating scientific knowledge in order to exercise their role as ecologically active and responsible citizens (ROOS; BECKER, 2012; BARRETO; VILAÇA, 2018), with the adoption of new habits in its relationship with the other elements of nature.

Guimarães (2016) emphasizes that EE gained greater global prominence in 1972, from the United Nations Conference on the Human Environment held in Stockholm. In addition, in Brazil, although there has already been an "environmentalist" movement since the 1980s, it was only with the preparations for the United Nations Conference on Environment and Development in Rio de Janeiro, in 1992, that the first attempts of implementation of EE in Basic Education and Higher Education started. The author also highlights the role of the teachers in incorporating the theme into their pedagogical practices over the years.

Nevertheless, EE already appears in the Brazilian Federal Constitution of 1988 (BRASIL, 1988), before the Rio 92. It is stated in Chapter IV, Article 225, Paragraph 1, item VI, that the Public Power must "promote environmental education in all educational levels and public awareness for the preservation of the environment". This was one of the first legal signs of the Brazilian government's concern with the issue. In 1997, the National Environmental Education Program (ProNEA) was created, revised in 2005 (BRASIL, 1999). And, in 1999, the National Policy of Environmental Education (PNEA) was established (BRASIL, 1999) issued by Law No. 9,795. The PNEA mandated EE as a mandatory curricular component at all levels of education and, in its first article, it reinforces the multidimensional aspect of $E E$, involving the society, education, and the environment, as defined by Layrargues and Lima (2014). 
The PNEA also mentions, as goals for EE, to develop in the individual the understanding of the environment and its relationships involving ecological, psychological, legal, political, and social aspects. On the other hand, ProNEA strengthened EE with a focus on integrating it into all sectors of the society, reinforcing its interdisciplinary and transversal, democratic, and social participation character (BRASIL, 2005). Despite the interdisciplinarity of EE mentioned in the PNEA and ProNEA, the Common National Curriculum Base, both for Elementary and High Schools, presents environmental themes with a focus on the subjects of Geography and Sciences or Biology and Physical Education, although with less emphasis in the latter (BRASIL, 2017).

It can be seen that Environmental Education in Brazil is well established in the legislation and government projects. In 2004, the National Institute of Educational Studies and Research Anísio Teixeira (INEP) found that around $90 \%$ of Brazilian schools carried out EE practices (BRASIL, 2013). However, this is only a quantitative analysis, therefore it is necessary to investigations that know how the theme is approached in the daily practice of schools. Thus, the objective of this study was to understand the perception of teachers in the final years of elementary education in public and private schools in Rio Grande do Sul, Brazil, about EA and its practice in schools, disregarding only the teachers who graduated in the areas of Biological Science and Geography.

\section{Methodology}

A questionnaire consisting of 30 multiple-choice and discursive questions (https://forms.gle/SkpwL3rtrbhcUsWv8) was prepared on Google Forms and sent through emails to regional schools and also directly to teachers, inviting them to participate in the study. The email showed the details of the research objectives, to whom it was directed, and also the link to access the questionnaire. The emails from the schools were obtained through an internet search looking for schools in the cities in the region, and the direct submission to the teachers consisted of personal contacts of the authors. Invitations were sent only once between August and September 2020 and the form was available for 30 days.

Upon accessing the link, the teachers were invited to read the Informed Consent Form (IFCF) and accept to participate in the research. By agreeing with what was stated in the IFCF, the teachers had access to the questionnaire. A requirement for approval of this research by the university's ethical committee was waived because of its nature, as being an anonymous online questionnaire about the general view and opinion of the participants about the subject in study, and because of the IFCF included with it.

Answers from teachers who graduated in Biological Sciences or Geography were not considered, as these areas involve the study of the environment. The present work aimed to continue the study by Jaeger and Freitas (2021), who investigated the perception of teachers linked to environmental sciences. The only Science teacher analyzed in our study is not 
a graduate in Biological Sciences.

A total of 36 teachers responded to the interview. The answers were inserted in an Excel spreadsheet and each participating teacher was identified by a code consisting of letters and numbers according to graduation, except for two teachers who were identified by two letters as they had two graduations (Table 1). One of the teachers graduated in Languages (L9) is also graduated in Family Farming, but this data is not included in the table, as it is not a degree linked to teaching. Then, the percentages of the multiple-choice questions were calculated and the subjective questions were analyzed.

Table 1: Teacher codes corresponding to their graduation courses. The number after the letters indicates the number of each teacher.

\begin{tabular}{cc}
\hline Teacher code(s) & Graduation course(s) \\
\hline AV1 & Visual Arts \\
CE1 a CE4 & Exact Sciences \\
EF1 a EF7 & Physical Education \\
F1 & Philosophy \\
H1 a H4 & History \\
HP & History and Pedagogy \\
L1 to L12 & Languages \\
M1 a M3 & Mathematics \\
MU1 & Music \\
Q1 & Chemistry \\
QF & Chemistry and Physics \\
\hline
\end{tabular}

Source: the authors.

\section{Results and discussion}

\section{Profile of the respondent teachers}

Of the 36 participating teachers, $33.3 \%$ were male and $66.7 \%$ were female and worked in schools in thirteen different cities. Of the total number of teachers, $22.2 \%$ worked only in private schools, $58.3 \%$ only in public schools, and $19.4 \%$ in both school systems. They graduated from 11 different courses, mostly in Languages (12), followed by Physical Education (seven), History (five), and Exact Sciences and Mathematics, both with three teachers. Most teachers $(22.2 \%)$ graduated 15 and 20 years ago, then the largest number of respondents graduated less than five years ago and between 10 and 15 years ago, both with $19.4 \%$ of the total number of participants (Figure $1 \mathrm{~A}$ ). Regarding the time of experience in the classroom, the majority $(25 \%)$ had been teaching for 15 and 20 years, followed by teachers $(22.2 \%)$ with a time of experience between 20 to 25 years (Figure 1B). There is a tendency for the time of experience as a teacher to be higher than the period since graduation, indicating that some started working as teachers during their graduation. 


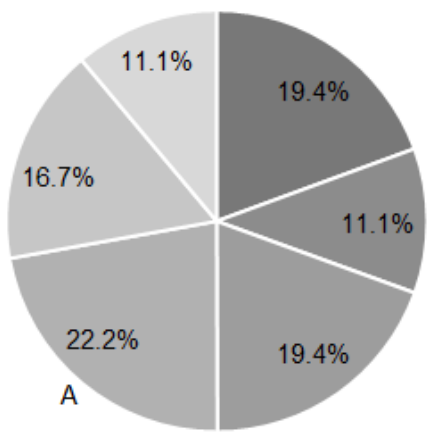

- Less than five years

॥ From five to 10 years

- From 10 to 15 years

- From 15 to 20 years

- From 20 to 25 years

- More than 25 years

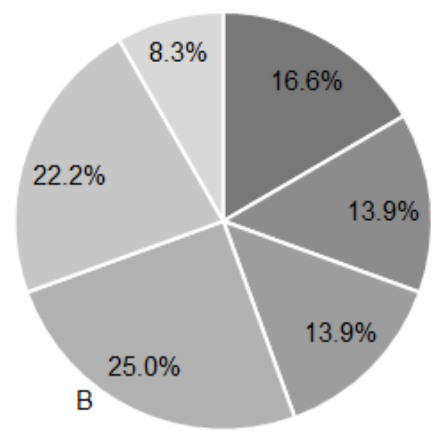

- Less than five years

- From five to 10 years

- From 10 to 15 years

- From 15 to 20 years

- From 20 to 25 years

- More than 25 years

Figure 1: Percentage of teachers that participated in the study per $(A)$ time since graduation and (B) time teaching. Source: the authors.

Participants were teachers on the following subjects: Arts, Sciences, Physical Education, Religious Education, Philosophy and Sociology, Physics, History, German, Spanish, English, and Portuguese languages, Literature, Mathematics, Music, Life Project, and Chemistry. Among them, most were Portuguese language teachers, followed by English language and Physical Education (Figure 2). Some of them also teach two, three, or even four subjects.

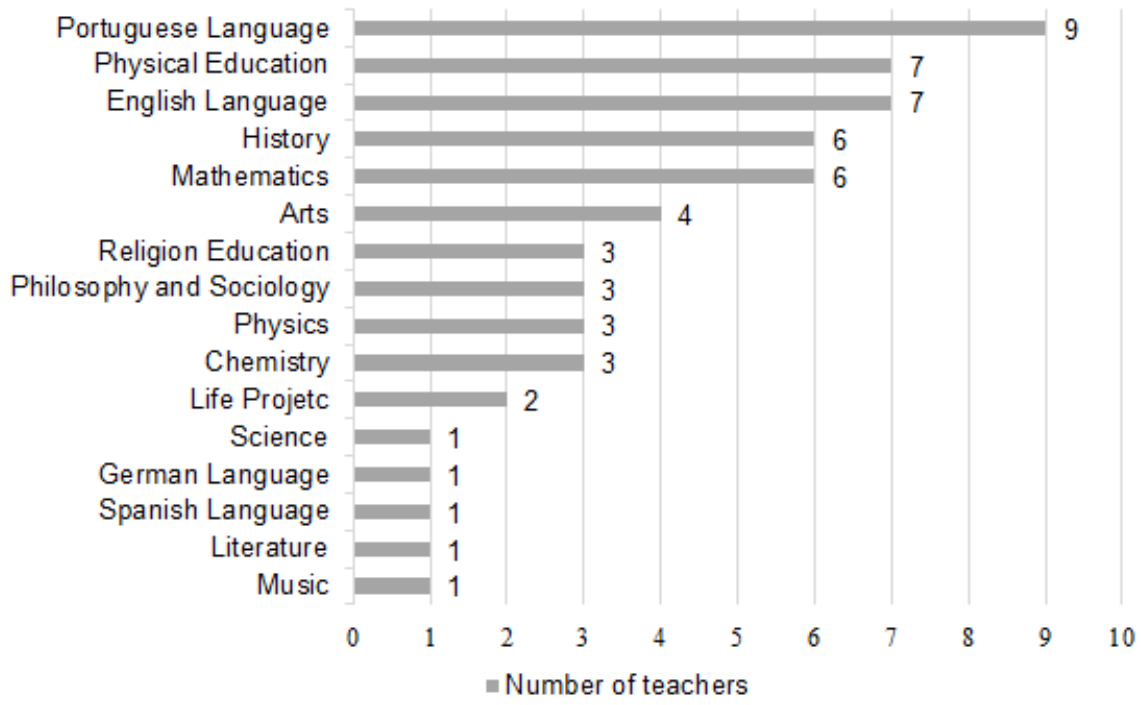

Figure 2: School subjects taught by the participants of the study with the respective number of teachers per subject. Source: the authors.

The objective of the Project of Life subject, taught by EF7 and L8 teachers in municipal schools in one of the municipalities, is to discuss interdisciplinary topics that do not find space in the workload of other disciplines, such as EE. And it is in line with Bernardes and Prieto (2010) who 
stated that public education networks, both municipal and state, seek to establish their own rules and parameters to integrate EE to the contents taught in Basic Education. However, it is noteworthy that, according to the PNEA, EE should appear in an interdisciplinary way, integrated into all disciplines (BRASIL, 1999).

\section{Teacher training for Environmental Education practices}

Of the total number of participating teachers, $75 \%$ responded that during their graduation, they were not trained to teach EE. According to the PNEA (BRASIL, 1999), the theme should be in all undergraduate courses, however, this requirement is not always met. Faria and Dinardi (2018), for example, evaluated undergraduate courses for teaching certificates at UNIPAMPA, Rio Grande do Sul, Brazil, and found that, among the 16 evaluated teachers, four did not discuss EE in any form. On the other hand, Hennrich Junior and Moreira (2019), while analyzing 14 undergraduate courses in Paraná, Brazil, observed that only one did not include EE in the curriculum. Guimarães and Inforsato (2012), studying educators who graduated in Biological Sciences in Piracicaba, São Paulo state, found that $43 \%$ of them did not discuss EE during their graduation.

Although most participants $(91.7 \%)$ consider that EE should be included in all undergraduate courses, some thought that it should only be addressed in specific courses, such as Physics, Chemistry, Geography, History, Pedagogy, and Biology, the latter with the highest number of indications. Although the statement that EE should only be addressed in specific courses, especially in Biological Sciences, was made by few participants, it demonstrates a lack of knowledge of the PNEA and the importance of topic.

As for being sufficiently trained during graduation or complementary courses to teach EE, only $11.1 \%$ thought it was enough, $19.4 \%$ considered it was not enough, while the highest percentage $(69.4 \%)$ was of teachers who were not trained to work in EE, which is alarming due to its importance nowadays. Professor L9 commented that the second degree in Family Farming and a postgraduation degree in EE was an adequate preparation, while others mentioned that the topic was approached superficially, with no specific credits assigned to it. Teachers EF6 and CE2 justified that during their graduation, about 20 and 25 years ago, respectively, the "environment was starting to be taken seriously" and there was no awareness of the topic, and PNEA did not even exist.

Similar to the high percentage of teachers who claim not to have had sufficient training in EE, mentioning lack of preparation for such and lack of knowledge about the subject or only superficial knowledge, $72.2 \%$ of them said they do not feel prepared to work with EE in schools, while only $27.8 \%$ consider themselves prepared. Professor $\mathrm{H} 4$ reports that he or she has already worked with EE when he or she was a scientific initiation scholarship holder during graduation, but still does not consider him or herself prepared. 
In addition, $83.3 \%$ of the respondents do not have a complementary course in EE, but $69.4 \%$ are interested in improving themselves on the subject. Most of them emphasize that such courses would be important to expand their knowledge and improve their teaching practice, recognizing their importance. Four teachers (MU1, H2, L6, L12) explained that they do not have time to take complementary courses; two others (CE2, Q1) mentioned that they are retiring, so they would not take the courses; and three (QF, L3, H3) were not interested in the topic. Teacher H3, now retired, added that EE would not be his or her area. Of the nine teachers who are not interested in specializing in the subject, only three (QF, CE2, L7) answered, in the previous question, that they feel prepared to work with EE in schools. It is believed that the teachers that feel unprepared and are not interested in taking EE courses probably do not develop activities on the subject during their classes or would do so inappropriately, not corresponding to the principles and objectives of their practice.

However, the PNEA (BRASIL, 1999) shows that taking EE courses is an obligation of all active teachers so that they can meet its principles and objectives. The lack of interest of some seems to be based on the misconception that EE would be important for some areas and not for others. In this sense, Oliveira (2015) states that the training of environmental educators would be a continuous and permanent process. These educators would also be responsible for articulating EE and maintaining a dialogue between the different subjects, participating in discussions and reflections that would help to break away from the traditional teaching that simplified certain phenomena of reality. This situation indicates that it is up to the municipal and state offices and to the Ministry of Education to implement programs so that teachers can update themselves in teaching practices in EE.

In comparison, in a study only with Science and Geography teachers, Jaeger and Freitas (2021) found that $60 \%$ did not take a complementary course to work in EE; Gasques et al. (2016) found that $53 \%$ and $65 \%$ of teachers from different subjects in two schools in Sarandi, in the state of Paraná, Brazil, did not have additional training in EE. The percentage of teachers without this training was much higher in our study, but this is probably because it does not involve Science, Biology and Geography teachers, opposite to the two studies mentioned. This reinforces the perception of most education professionals that EE should be carried out by teachers in the areas of Life Sciences, especially Biology and Geography.

\section{Environmental Education in Educational and Political Projects}

The Political-Pedagogical Project or PPP is a collectively elaborated document based on the discussion and dialogue of the school community and aims to structure and organize the pedagogical work of schools. It deals with the pedagogical and administrative structures of the school, the curriculum, the school calendar, and assessments, among other aspects. However, what is

addressed in the PPP must follow the legislation related to Education, granting

revista brasileira educação ambiental 
the school to decide the emphasis to be given to each subject (VEIGA, 2013). Thus, EE is one of the themes that can appear in different ways in PPPs. The PNEA does not specify the incorporation of EE in the PPP, but imposes that it must be included in school activities through training of human resources, development of studies, research and experiments, production and dissemination of educational material, and following up and evaluation; these topics can be linked to PPP.

In this study, $47.2 \%$ of teachers were unable to answer whether the PPP of the school where they work discusses EE (Figure 3A). Only six responded, indicating little knowledge about EA in PPP despite stating that they know it because three teachers (EF3, EF7, L10) mentioned that EE is a crosscutting theme, while three others (EF4, EF6, L2) reported that it is discussed in projects in Science and Biology. This last answer also indicates that the PPP is not under the PNEA or that the teacher is not aware of it. Professor L9 describes that the subject is worked through texts - probably highlighting this aspect only in his subject (Portuguese language). EF1 commented that at the school where he or she works, "EE is a mandatory subject in the curriculum". It is noteworthy, however, that the PNEA states that EE cannot be implemented as a specific subject in the curriculum, except in postgraduation and extension courses (BRASIL, 1999). In this sense, Bernardes and Prieto (2010) state that in Brazil there are many requests from lawmakers and entities for the inclusion of EE as a separate subject in the Basic Education curriculum, but they emphasize that its implementation would be against federal legislation. Tavares (2013) also mentions that the creation of such a discipline, separately, configures disregard for the PNEA (BRASIL, 1999).

As for considering as adequate what is shown about EE in the PPP of schools, $58.3 \%$ of respondents did not have an opinion about it (Figure 3B). If compared to the percentage of teachers who claim not to know if $E E$ is addressed in their school's PPP, it is clear that some, despite knowing that it is addressed, do not know how this is done. Among the others, $38.9 \%$ said it is adequate and only $2.8 \%$, the equivalent of one teacher (L12), said it is not adequate. In addition, some teachers demonstrate that they understand the importance of the topic when they comment that EE should be included in the PPP more broadly, covering more subjects, integrating more the community, or that there should be more projects that discuss it. Teacher L5 suggests the implementation of some type of project related to the collection and sale of waste, to use the collected money to carry out some improvements in the school. 


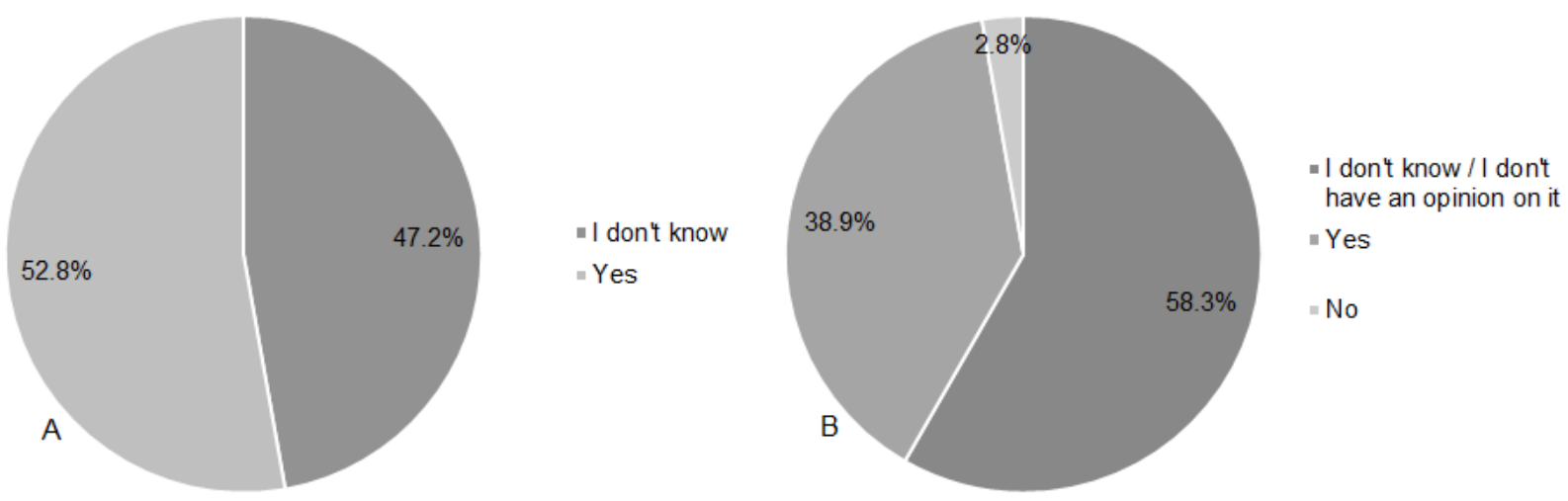

Figure 3: (A) Percentage of teachers aware of the Environmental Education content in their school's Political-Pedagogic Project and (B) percentage of teachers that consider that the content is adequate. Source: the authors.

\section{Environmental Education under the teachers' point of view}

Most educators $(97.2 \%)$ think that EE practices should be common in the subject they teach, not delegating them only to Biology or Science and Geography teachers, for example. This majority also highlighted, in some way, the importance of teaching EE in an interdisciplinary way. Only one teacher (L12) reported that because of the lack of training, he or she does not see these practices as part of his or her subject.

As for the development of EE activities in the subjects they teach, $61.1 \%$ have already developed some activity, most evaluating it positively. Ten teachers mentioned carrying out activities performed in this context (Table 2), among which four cited recycling and disposal of solid waste and residues. AV1, Art teacher, highlights activities such as the creation of works by artist Vik Muniz, who uses alternative materials in his works (SILVA; MARQUES, 2019), and the Land Art artistic movement, which consists of the outdoor construction of architectural works, based on the natural landscape (ENGLAND, 2017). Teacher L1 also mentioned that activities performed in their class, without specifying which, could have been more dynamic, related to other subjects. 
Table 2: Activities developed by the teachers in their school subjects that are considered to include Environmental Education with the respective citation number and teacher.

\begin{tabular}{|c|c|}
\hline $\begin{array}{l}\text { Number the citations } \\
\text { and Teachers }\end{array}$ & Activities developed in the subjects \\
\hline 1 (AV1) & $\begin{array}{l}\text { Sculptures construction using alternative materials, research on Vik } \\
\text { Muniz and Land Art. }\end{array}$ \\
\hline $\begin{array}{c}4 \text { (CE1, EF5, EF6, and } \\
\text { L5) }\end{array}$ & Recycling and disposal of solid residue and waste. \\
\hline 1 (CE3) & $\begin{array}{l}\text { Construction of an electric generator using coolers from used } \\
\text { computers. }\end{array}$ \\
\hline 1 (CE4) & Construction of cisterns using truck tires. \\
\hline 1 (EF4) & $\begin{array}{l}\text { Tracks and investigations on sports that can be performed in } \\
\text { nature. }\end{array}$ \\
\hline $1(F 1)$ & Research on swamps. \\
\hline 1 (L9) & Studies with texts on the environment. \\
\hline 1 (M3) & Research on alternative energy sources. \\
\hline
\end{tabular}

Source: the authors.

On the other hand, $94.4 \%$ of teachers responded that EE should be taught in an interdisciplinary way, while only two (L3 and L12) answered no. This contradicts the answers to previous questions, in which teachers indicate specific undergraduate courses that must include training in EE or the fact that they are not interested in taking additional courses, despite being unprepared to work in EE. The answers suggest that, even if teachers agree that EE is an interdisciplinary topic and should be treated as such, they effectively do not practice this interdisciplinarity or, if they eventually do so, they only follow the school's demands or requirements. Morrison (2018) states that this is generally the case. For the author, when EE is not a specific demand of content or grade, the decision to bring it and work it in the classroom reflects the teacher's values and beliefs and not necessarily their education or academic preparation for such.

Regardless of their participation in such activities, $77.8 \%$ of teachers responded that EE projects or activities are developed in their schools (Table 3 ), while five stated that they do not have any EE projects or activities where they teach. As in the activities carried out individually by the teachers at the school level where they work, there is also a predominance of activities for solid waste sorting, with ten citations, management of school gardens, and collection of various waste, both with five citations, which actually does not configure EE.

According to Carvalho (2016), EE should imply the development of an ecological individual, who would seek to solve social and ethical dilemmas associated with the socio-environmental crisis, configuring a more socially just and sustainable world. This process would be broad, necessarily transforming the relationship between society and the environment. Then, it is questioned whether the EE activities, cited by the teachers participating in the research as 
carried out in the schools where they work, can promote environmental awareness in students, the development of critical citizens meeting the objectives of EE cited by the law and, above all, the transformation of the thought, necessary for them to become ecological individuals. In this regard, the educators who participated in the research showed doubts about the activities being adequate and following the PNEA, as only $41.7 \%$ said they were adequate, while $13.9 \%$ considered them inadequate and $44.4 \%$ did not show any opinion.

Table 3: List of projects and activities developed in the schools according to the citation of teachers and the respective number of citations.

\begin{tabular}{|c|c|}
\hline Activities or projects & $\begin{array}{l}\text { Number of } \\
\text { citations }\end{array}$ \\
\hline Solid waste sorting & 10 \\
\hline Diverse reside collection & 5 \\
\hline School Garden management & 5 \\
\hline Project on used cooking oil collection & 4 \\
\hline Scientific investigation projects & 3 \\
\hline School courtyard cleaning & 2 \\
\hline $\begin{array}{l}\text { Annual definition of a topic on the environment for execution of } \\
\text { activities }\end{array}$ & 2 \\
\hline Tree planting & 2 \\
\hline Paper recycling & 2 \\
\hline Rainfall water collection & 2 \\
\hline $\begin{array}{c}\text { Project on one day a week free of garbage (each one of us is } \\
\text { responsible for our garbage) }\end{array}$ & 1 \\
\hline Thinking actions in the Environment Week & 1 \\
\hline $\begin{array}{c}\text { Development of stories [on the environment] according to the } \\
\text { students' ideas }\end{array}$ & 1 \\
\hline Games [involving activities related to EE] & 1 \\
\hline Composting container building & 1 \\
\hline Activities for water waste awareness & 1 \\
\hline Attendance in lectures & 1 \\
\hline Visits to the city's Botanical Garden & 1 \\
\hline Activities on conscious consumption & 1 \\
\hline
\end{tabular}

Source: the authors.

In general, the justifications for those who considered the activities to be adequate in relation to the PNEA are the variety of activities carried out, the involvement of the school community, the involvement of students who act as 
protagonists of practical activities, and their visible awareness in the environment preservation. On the other hand, the group that considered them inadequate justifies this position with the perception that students do not understand the meaning of such activities, that they lack involvement, that activities should be more incisive, or even that not many actions are performed. In addition, a teacher stated that he or she did not know how to give an opinion because it is difficult to acknowledge if the students understand the meaning of the activities. The opinion of teachers in relation to these positions needs to be considered, both in schools during the PPP planning as well as by the Ministry of Education and state and municipal offices of Education.

Regarding recycling and garbage collection, Andrade and Sorrentino (2013) point out that, despite their importance, they end up transforming the school into an essentially objective environmental manager, often playing the role that it should be of companies and public bodies. These practices, along with others, such as school gardens and composting areas, only have real meaning within the school when pedagogical, political, philosophical, and scientific issues are extracted from them, providing a challenge for the student's critical sense and reflection. Practices are no longer instrumental approaches and gain meaning for the subjects that put them into practice. The fact that students can collect packaging from the schoolyard, for example, does not necessarily imply a reflection on consumerism, health, or solid waste policies.

In a survey conducted in eight elementary schools in the municipality of Araraquara, in the state of São Paulo, Brazil, Ferrari and Zancul (2016) concluded that teachers carry out EE activities with no theoreticalmethodological foundation in a way that it is critical and emancipatory, however, it was performed, in general terms, by what is recommended by the legislation. It is observed that the present study showed a similar situation, in which teachers, in addition to not having a foundation to practice EE, lack an understanding of what it really is, reducing it to meaningless practices. It is important that teachers, such as coordination and direction of schools, are prepared to understand the legislation.

Regarding what could be changed in EE practices in schools, many of the respondents pointed out that EE actions, activities, and projects should be expanded, performed in an interdisciplinary way and in a "natural way within the subjects, not just at specific moments"; be related to the local needs of the community and supported by environmental agencies. These reflections are under the guidelines of the PNEA (BRASIL, 1999), as it states that EE must meet different demands of society and be executed in an integrated manner in the subjects, given its multiple dimensions.

As for the participation of teachers in these EE activities in schools, $30.5 \%$ reported that they contribute little or nothing to these projects, while $52.8 \%$ said they contribute or get involved in some way. Teacher EF2 commented that the teachers responsible for these activities are designated according to the credits and classes in which they work, without specifying 
whether his or her participation was active. Also, half of the respondents (50\%) indicated that the activities are generally under the responsibility of the Biology or Science teachers, and a smaller percentage (16.6\%) indicated the coordination or direction of the school as the main responsible. Teacher $\mathrm{H} 4$ indicated as in charge the coordination of the school and the teacher of the Life Project subject, in which interdisciplinary matters are dealt with in elementary schools in a city in the state of Rio Grande do Sul.

In the Common National Curriculum Base (BNCC) (BRASIL, 2017), the term "life project" appears several times, especially for high school, being defined as what students aspire to and define for themselves throughout their lives. One of the general competencies of Basic Education would be precisely to promote the acquirement of knowledge and experiences for the best exercise of citizenship and guide the choices related to the student's life project. In this sense, as previously mentioned, referring to Layrargues and Lima (2014), due to the multidimensional character of EE, Life Project fits as a subject and may reduce the interdisciplinarity of $E E$, being limited to a specific subject, without dialogue with the others.

The majority $(63.9 \%)$ of teachers also commented that students are generally involved and enjoy EE activities. However, according to Teacher EF1, the reaction of students depends on what is proposed to them, while Teacher CE3 reported that he or she perceives different situations, as he or she works in schools in three municipalities. In one of the schools, students are very participatory, while in the other two, it has been difficult to change their behavior.

Most of the teachers that responded to the questionary (72\%) believe that the responsibility for developing EE activities should be shared by everyone, as teachers, coordination, and direction. Seven respondents (MU1, EF6, L3, L4, H3, L12) stated that Science, Biology, or Natural Sciences teachers, in general, should be responsible for these activities. Teacher AV1, despite agreeing that it should be everyone's responsibility, mentioned that the most active should be Science and Geography teachers; yet, CE3 indicated Physics, Chemistry, Geography, Biology, and Sciences. Again, teacher H4 suggested that the Life Project teacher should be the main responsible. On the other hand, the inclusion of EE as an independent subject appeared in the speech of teacher L9, defending its inclusion, since the teachers "do not complete" the minimum content proposed in their subjects, making it difficult to deal with other issues. Gasques et al. (2016), as in the present study, also reported that Science and Geography are the subjects most recommended by teachers from two schools in Sarandi, Paraná, Brazil, to carry out EE activities. As previously mentioned, in BNCC (BRASIL, 2017), the focus of EE is also on these subjects, but it is also discussed in Physical Education, which curiously does not appear in the present study and, despite being mentioned, is also little emphasized on the work of Gasques et al. (2016). 
Finally, the teachers listed all the elements they would draw to answer "What is nature to you?" (Table 4). Of the total respondents, $55.6 \%$ did not place the human being as part of nature; two of them specified that they considered as nature everything that is "untouched" or "not-created" by human beings. According to Santos and Imbernon (2014), the idea that man is not part of nature is as much heritage from Antiquity, from the thoughts of Aristotle, as from the Christian theology that emerged in the Middle Ages, and from the 16thcentury philosophers who placed the human being as the dominator and transformer of the nature. Only in the 20th century, coinciding with the advent of $\mathrm{EE}$, there is a transformation in the principles, with the emergence of the term environment. Dias (2013) states that this separation between human beings and nature ends up serving as a justification for the destruction of ecosystems. Thus, it is worrisome that teachers have this conception, as it will inevitably reflect on their actions when working with EE.

Table 4: Lists of elements that the teachers would draw in the intent of answering the question "What is nature to you?".

\begin{tabular}{|c|c|c|}
\hline Teacher & Suggested elements & $\begin{array}{l}\text { Does it include } \\
\text { human beings? }\end{array}$ \\
\hline AV1 & $\begin{array}{l}\text { Nature, animals, groups including human beings, fungi, } \\
\text { bacteria, protists, and the Plant Kingdom. }\end{array}$ & Yes \\
\hline CE1 & The sun, water, soil. Tress, pants, animals, and people. & Yes \\
\hline CE2 & Planet Earth, plants, animals, people, water, air. & Yes \\
\hline CE3 & $\begin{array}{l}\text { Animals, plants, viruses, bacteria, water, minerals, } \\
\text { rocks, planets, stars, comets, natural satellites, waves, } \\
\text { light, and energy. }\end{array}$ & No \\
\hline CE4 & Planet Earth: beings. & No \\
\hline EF1 & The Universe. & No \\
\hline EF2 & $\begin{array}{l}\text { Water, trees, rocks, Planet Earth, the sun, rain, } \\
\text { garbage, people, industries, constructions, } \\
\text { automobiles. }\end{array}$ & Sim \\
\hline EF3 & $\begin{array}{l}\text { Mother, balance, breathing, life, health, peace, food, } \\
\text { oxygen, mood swings, human being. }\end{array}$ & Yes \\
\hline EF4 & $\begin{array}{l}\text { Trees, flowers, water, the sun, gases, clouds, people, } \\
\text { animals. }\end{array}$ & Yes \\
\hline EF5 & $\begin{array}{l}\text { Planet Earth, hills, trees, flowers, animals, people, } \\
\text { rocks, water, the sun, the clouds. }\end{array}$ & Yes \\
\hline EF6 & $\begin{array}{l}\text { The sky, clouds, birds, trees, water, Planet Earth, } \\
\text { human beings, animals, buildings: everything around } \\
\text { us. }\end{array}$ & Yes \\
\hline EF7 & Life, peace, freedom. & No \\
\hline $\mathbf{F 1}$ & $\begin{array}{l}\text { Planet Earth, cities, forests, rivers, people, and } \\
\text { animals. }\end{array}$ & Yes \\
\hline H1 & $\begin{array}{l}\text { I, mountains, trees, rivers, animals, the sky, the sun, } \\
\text { the clouds. }\end{array}$ & Yes \\
\hline
\end{tabular}


,,,continuation.

\begin{tabular}{|c|c|c|}
\hline Teacher & Suggested elements & $\begin{array}{l}\text { Does it include } \\
\text { human beings? }\end{array}$ \\
\hline $\mathrm{H} 2$ & $\begin{array}{l}\text { Trees, flowers, diverse vegetation, running water, rain, } \\
\text { the sun, wind. }\end{array}$ & No \\
\hline H3 & Water, soil, plants, animals, air, the sun. & No \\
\hline H4 & Fresh air, cleanliness. & No \\
\hline HP & Nature, space, society & Yes \\
\hline L1 & Tree, river, animals, clean air. & No \\
\hline L2 & $\begin{array}{l}\text { Human beings, animals, plants, earth, water, air, rocks; } \\
\text { diverse natural landscapes, and the relationships } \\
\text { among all these elements. }\end{array}$ & Yes \\
\hline L3 & The universe. & No \\
\hline L4 & $\begin{array}{l}\text { Life, happiness, freedom, respect, synchrony, } \\
\text { Harmony, boundaries, purity, innocence. }\end{array}$ & No \\
\hline L5 & $\begin{array}{l}\text { Waterfall, rain, a field with flowers of different species, } \\
\text { with rich and diverse fauna and, far in the field it would } \\
\text { be possible to see a dense forest and behind it, green } \\
\text { hills and mountains and if I climbed one of them, I } \\
\text { would see a beautiful orchard in the valley and full of } \\
\text { life. }\end{array}$ & Yes \\
\hline L6 & Planet Earth, trees, water, soil, air, fire, rain. & No \\
\hline L7 & Water, fauna, flora, and earth. & No \\
\hline L8 & $\begin{array}{l}\text { Everything that was on the planet before being touched } \\
\text { by human beings. }\end{array}$ & No \\
\hline L9 & Natural landscape untouched by human beings. & No \\
\hline L10 & Trees, rivers, flowers, plants. & No \\
\hline L11 & $\begin{array}{l}\text { Huge trees and their shades, animals, and humans } \\
\text { living in harmony }\end{array}$ & Yes \\
\hline L12 & Trees, Flowers, forests, the sun, rain, animals. & No \\
\hline M1 & $\begin{array}{l}\text { Life, death, fauna, flora, microscopical beings, } \\
\text { everything not created by humans except humans } \\
\text { themselves. }\end{array}$ & No \\
\hline M2 & Water, air, soil, nature, garbage, animals, & No \\
\hline M3 & $\begin{array}{l}\text { House, sun, nature, water, animals, sustainable and } \\
\text { integrated environment. }\end{array}$ & No \\
\hline MU1 & Trees, streams, waterfall, hills, Flowers, and animals. & No \\
\hline Q1 & Planet Earth and everything in it. & Yes \\
\hline QF & $\begin{array}{l}\text { Physical and chemical elements, trees, water, flower, } \\
\text { animals, people. }\end{array}$ & Yes \\
\hline
\end{tabular}

Source: the authors.

In comparison, in a similar study carried out by Jaeger and Freitas (2021) with elementary school teachers from public schools in the state of Rio Grande do Sul teaching Science and Geography, only two of the 10 respondents did not include the human being as part of nature. The percentage of teachers $(20 \%)$ who did not include human beings among the elements of nature in the work of 
Jaeger and Freitas (2021) is much lower than that of our study (55.6\%), demonstrating that teacher training probably has direct interference in their responses and activities as environmental educators.

\section{Conclusion}

Elementary school teachers participating in our research and who do not work in the areas of Biology, Science, and Geography acknowledged the practice of EE as important in schools, that it should be interdisciplinary, but they do not have training for its practice. Teachers demonstrated not knowing the PNEA and knowing little about the PPP of their schools. Also, they confirmed that the EE practices carried out are still limited and lack deepening and meaning in the sense of forming, in students, ecological and critical individuals, aware of their role in environmental preservation.

\section{Acknowledgments}

The authors thank the teachers that took part in this study by answering the questionnaire.

\section{References}

ANDRADE, D. F.; SORRENTINO, M. Da gestão ambiental à Educação Ambiental: as dimensões subjetiva e intersubjetiva nas práticas de Educação Ambiental. Pesquisa em Educação Ambiental, São Paulo, v. 8, n. 1, p. 88-98, 2013.

BARRETO, L. M.; VILAÇA, M.T.M. Controvérsias e consensos em educação ambiental e educação para o desenvolvimento sustentável. Research, Society and Development, Vargem Grande Paulista, v. 7, n. 5, p. 01-18, 2018.

BERNARDES, M. B. J.; PRIETO, E. C. Educação Ambiental: disciplina versus tema transversal. Revista Eletrônica do Mestrado em Educação Ambiental, Rio Grande, v. 24, 2010.

BRASIL. Constituição da República Federativa do Brasil de 1988. Brasília, DF, $1988 . \quad$ Disponível em: <http://www.planalto.gov.br/ccivil 03/constituicao/constituicao.htm>.Acesso em: 25 out. 2020.

BRASIL. Lei No 9.795, de 27 de abril de 1999. Dispõe sobre a educação ambiental, institui a Política Nacional de Educação Ambiental e dá outras providências. Brasília, DF 1999. Disponível em: <http://www.planalto.gov.br/ccivil 03/leis/l9795.htm>. Acesso em: 25 out. 2020. 
BRASIL. Ministério da Educação e Ministério do Meio Ambiente. Programa Nacional de Educação Ambiental - ProNEA. 3. ed. Brasília, DF: MMA, 2005. Disponível em: $<$ https://www.mma.gov.br/estruturas/educamb/ arquivos/pronea3.pdf $>$. Acesso em: 26 out. 2020.

BRASIL. Ministério da Educação. Secretaria de Educação Básica, Secretaria de Educação Continuada, Alfabetização, Diversidade e Inclusão. Secretaria de Educação Profissional e Tecnológica. Diretrizes Curriculares Nacionais Gerais da Educação Básica. Brasília, DF: MEC, SEB, DICEI, 2013.

BRASIL. Base Nacional Comum Curricular (BNCC). Educação é a Base. Brasília, DF: MEC/CONSED/UNDIME, 2017. Disponível em: $<$ http://basenacionalcomum.mec.gov.br/images/BNCC El EF 110518 versaofi nal site.pdf>. Acesso em: 26 out. 2020.

BURSZTYN, M. A.; BURSZTYN, M. Fundamentos de política e gestão ambiental: caminhos para a sustentabilidade. Rio de Janeiro: Editora Garamond Ltda, 2013.

CARVALHO, I. C. M. Educação ambiental: A formação do sujeito ecológico. 6. ed. São Paulo: Cortez Editora, 2016.

DIAS, G. F. Atividades interdisciplinares de educação ambiental. 1. ed. São Paulo: Global Editora e Distribuidora LTDA, 2013.

ENGLAND, E. The Archive of Place and Land Art as Archive: A Case Study of Spiral Jetty. The American Archivist, Chicago, v. 80, n. 2, p. 336-354, 2017.

FARIAS, N. R.; DINARDI, A. J. A temática ambiental nos cursos de licenciatura da Universidade Federal do Pampa. Educação Ambiental em Ação, v. 17, n. 64, 2018.

FERRARI, A. H.; ZANCUL, M. C. S. Aproximações entre os contextos local e nacional em práticas de Educação Ambiental nas escolas. Revista Brasileira de Educação Ambiental, São Paulo, v. 11, n. 1, p. 66-84, 2016.

GASQUES, A. C. F.; OKAWA, C. M. P.; SANTOS, J. D.; GASQUES, E. G. F.; DELABIO, F. Educação ambiental: estudo de caso em dois colégios estaduais da cidade de Sarandi (PR). Revista Brasileira de Educação Ambiental, São Paulo, v. 11, n. 5, p.123-138, 2016.

GELAIN, A. J. L.; LORENZETT, D. B.; NEUHAUS, M.; RIZZATTI, C. B. 2012. Desmatamento no Brasil: um problema ambiental. Revista Capital Científico, v. 10, n. 1, 2012.

GUIMARÃES, M. Por uma educação ambiental crítica na sociedade atual. Revista Margens Interdisciplinar, Abaetetuba, v. 7, n. 9, 2016.

GUIMARÃES, S. S. M.; INFORSATO, E.C. A percepção do professor de Biologia e a sua formação: a Educação Ambiental em questão. Ciência \& Educação, Bauru, v. 18, n. 3, p. 737-754, 2012. 
HENNRICH JUNIOR, E. J.; MOREIRA, A. L. O. R. A Educação Ambiental nas licenciaturas: uma análise curricular em uma Instituição de Ensino Superior Pública do Paraná. Ambiente \& Educação, Rio Grande, v. 24, n. 2, p. 437456, 2019.

JAEGER, A. P.; FREITAS, E. M. Prática de Educação Ambiental: percepção de professores do Ensino Fundamental de escolas públicas municipais do Rio Grande do Sul. Revista Brasileira de Educação Ambiental, São Paulo, v.16, n. 2, p. 23-34, 2021.

LAYRARGUES, P. P.; LIMA, G. F. G. The Brazilian environmental education macro-political-pedagogical trends. Ambiente \& Sociedade, São Paulo, v. 13, n. 1, p. 23-40, 2014.

MORRISON, S. A. Everyday environmental education: five practices of ecologically minded teachers. Environmental Education Research, Abingdonon-Thames, v. 24, n. 1, p. 1527-1545, 2018.

OLIVEIRA, M. A. N. (Re)pensando a formação de professores em Educação Ambiental. Revista Monografias Ambientais, Santa Maria, v. 14, 2015.

PROFICE, C. C. 2016. Educação Ambiental: dilemas e desafios no cenário acadêmico brasileiro. Revista Eletrônica do PRODEMA, v. 10, n. 1, p. 22-37, 2016.

ROOS, A.; BECKER, E. L. S. Educação Ambiental e Sustentabilidade. Revista Eletrônica em Gestão, Educação e Tecnologia Ambiental, v. 5, n. 5, p. 857866, 2012.

SERRAGLIO, D. A.; FERREIRA, H. S.; MENDES, R. L. M. A atuação do poder judiciário brasileiro nos biomas Amazônia e Cerrado visando combater o aquecimento global. Revista da Faculdade de Direito da UFG, Goiânia, v. 42, n. 2, p. 11-47, 2018.

SILVA, C. P.; MARQUES, J. A. Processos de legitimação e permanência no mercado de arte: uma análise da trajetória dos artistas Andy Warhol e Vik Muniz. Extraprensa, São Paulo, v. 12, p. 136-15, 2019.

SANTOS, J. A. E.; IMBERNON, R. A. L. A concepção sobre "natureza" e "meio ambiente" para distintos atores sociais. Terrae Didatica, Campinas, v. 10, n. 2, p. 151-159, 2014.

TAVARES, G. S. O que pensam os professores sobre a criação de uma disciplina de Educação Ambiental? Revista Brasileira de Educação Ambiental, São Paulo, v. 8, n. 1, p. 83-90, 2013.

VEIGA, I. P. A. Projeto Político-Pedagógica da escola: uma construção coletiva. In: Veiga, I. P. A. (Org.) Projeto Político-Pedagógico da escola: uma construção possível. Campinas: Papirus Editora, 2013. p. 11-35. 